\title{
JOINT TRADE LIBERALIZATION AND TAX REFORM IN A SMALL OPEN ECONOMY: THE CASE OF EGYPT
}

Denise Konan and Keith E. Maskus

\section{CENTRE FOR INTERNATIONAL}

\section{ECONOMIC STUDIES}

University of Adelaide

Adelaide S.A. 5005

Australia

October 1997 
CIES SEMINAR PAPER 97-13

\title{
JOINT TRADE LIBERALIZATION AND TAX REFORM IN A SMALL OPEN ECONOMY: THE CASE OF EGYPT
}

\author{
Denise Konan
}

University of Hawaii

Keith E. Maskus

University of Colarado

\section{October 1997}

This research was supported in part by The World Bank. The analysis and opinions in this paper are those of the authors and do not necessarily represent those of the World Bank. We are grateful to James Alm, Glenn Harrison, Bernard Hoekman, David Richardson, Thomas Rutherford, David Tarr, Rod Tyers, Neil Vousden, Alan Winters, and seminar participants at the University of Adelaide, Australian National University, Purdue University and Syracuse University for comments.

ISBN 0863963676 


\section{ABSTRACT \\ Joint Trade Liberalization and Tax Reform in a Small Open Economy: The Case of Egypt}

\section{by Denise Konan and Keith E. Maskus}

We develop a computable general equilibrium model of the Egyptian economy. The model is suitable for analyzing the impacts of reforms in the tax system, the trade-policy regime, or both taken together. A two-sector, general-equilibrium model is presented diagrammatically to illustrate the separate and joint effects of distortionary capital taxes, consumption taxes, and tariffs. Thus, trade or tax reform may be undertaken conditionally upon maintenance of the other distortions or may be undertaken in a combined policy package. We compute the welfare gains from various policy changes, along with impacts on the real exchange rate and on real factor prices, allowing tax rates to vary endogenously to satisfy a fixed real revenue target for the Egyptian government. Scenarios include removal or unification of the consumption tax, the capital tax. Or both, and tariff unification, a free-trade agreement with the European Union, and unilateral tariff elimination. Welfare effects depend critically on the reform undertaken and the type of replacement tax. While both are important, neither trade-policy reform nor tax reform dominates. We also calculate interaction effects between policy regimes.

Keywords: Tax reform, trade liberalization, welfare gain

JEL Classification: F13, F15, H21

Contact Author:

Keith E. Maskus

Department of Economics

University of Colorado

Boulder, Colorado 80309-0256

USA

Phone: (303) 4927588

Fax: (303) 4928960

Keith.Maskus@colorado.edu 


\section{NON-TECHNICAL SUMMARY}

Trade liberalisation programs take place against a backdrop of economies characterised by distortions such as intersectorally variable factor taxes and commodity taxes. Applied general-equilibrium models rarely have accounted for the implications of such distortions for the gains (or losses) from reforms in trade policy. We argue that the extent of such gains is dependent both on the structure of underlying distortions and on any endogenous changes in tax policy that may emerge in response to liberalisation. Thus, standard models that simply compute the gains from trade reforms without incorporating distortions and their interactions with tariff cuts are, at best, conditional measures. In fact, such gains are misstated if they are attributed solely to changes in trade policy and are misleading about the true gains available from trade liberalisation in the face of tax distortions. These points are demonstrated analytically with a two-sector general equilibrium model that allows tariffs and sectorally differentiated taxes.

This paper investigates the importance of such interactive effects with a computable general equilibrium (CGE) model of trade liberalisation developed for Egypt. The model is used to simulate different potential trade reform measures, including tariff unification, a free trade agreement (FTA) with the European Union, and unilateral free trade on a global basis. The simulations are performed against an idealised backdrop of lump-sum taxation and against the existence of two types of intersectorally distortionary taxes, one on capital use and one on consumption of commodities. Further, the taxes are subject to individual or joint reform, either via sectoral unification of tax rates or removal, in all scenarios, allowing a comparison of welfare impacts.

A key element of the approach is to allow the tax instruments to vary endogenously within the model to replace lost government revenues when trade is liberalised or taxes are reformed. It is crucial in applied settings to permit endogenous tax responses because governments engaged in policy reform are concerned about implications for fiscal revenues and the follow-on need to raise taxes for replacement purposes.

With this technique, it is possible to decompose total welfare changes from policy reform into a pure trade-reform effect, a tax-reform effect, and an interaction term representing the joint inefficiencies of the two regimes in the combined system. The interaction term reflects the fact that either reform alone will produce some gains that overlap those of the other reform. For example, consider an importable commodity that is subject to a tariff and a consumption tax levied on the tariff-inclusive domestic price. Removal of the tariff alone generates both a consumer-surplus gain and higher consumption-tax revenues produced by additional imports. Removal of the consumption tax alone generates a different consumer-surplus gain and higher tariff revenues. The sum of these effects double-counts some overlapping welfare gains and overstates gains from joint reform. However, there are net efficiency gains from joint reform that are unavailable from either individual policy change, implying that the interaction term could 
be positive or negative.

The CGE model contains 39 sectors with all products and services serving as both final goods and intermediates. Traded goods and services are differentiated by region, including the European Union, countries of the Middle East and North Africa, the United States, and the rest of the world. The model is calibrated with data on production, consumption, trade flows, tariffs, and tax rates in 1994. The model is static in nature and computes long-run changes in outputs, trade, welfare, the real exchange rate, and real factor prices assuming intersectorally mobile labor and capital.

To summarise briefly the many simulation results, the model indicates that different tax reforms and trade reforms promise different levels of welfare gains and that these gains are dependent on responses in tax rates. The capital tax is highly distortionary, so that any policy change that would result in higher capital taxes significantly limits welfare gains or actually makes the economy worse off. A corollary result is that, since the consumption tax is less distortionary, its use for revenue replacement provides the largest gains in most scenarios. However, some policy reforms, such as tariff unification, raise tariff revenues and allow a reduction in capital taxes or commodity taxes, thereby markedly increasing the gains to liberalisation. For any tax system, Egypt tends to gain the most from unilateral free trade, second-most from tariff unification, and least from an FTA among the trade-reform options. For the given set of trade distortions, Egypt tends to gain most from jointly reforming the capital and commodity taxes, second-most from reforming the capital tax, and least from reforming the consumption tax.

The decomposition exercises indicate that both trade reform and tax reform are important for raising Egyptian efficiency and welfare. For example, joint tax reform taken alone (with an idealised lump-sum replacement tax) would raise welfare by $1.09 \%$ of initial consumption (using an equivalent-variation measure), while unilateral free trade taken alone would raise welfare by $0.89 \%$. If these policies were performed together, however, the welfare gain would be $1.63 \%$, which is less than their sum. Thus, taxes and trade distortions interact to reduce their individual inefficiencies in the economy by some $0.35 \%$ of aggregate consumption. 


\title{
Joint Trade Liberalization and Tax Reform in a Small Open Economy:
}

\author{
The Case of Egypt
}

\section{Denise Konan and Keith E. Maskus}

\section{Introduction}

Most models of the welfare effects of trade liberalization programs presume the absence of distorting taxes in the economy, adopting the textbook assumption that the tax system relies on non-distortionary lump-sum instruments. Under such ideal circumstances, the calculated welfare effects represent pure welfare gains from trade liberalization. However, actual trade reform takes place against a backdrop of distortionary taxes on factor use and commodities. In this context, welfare gains from trade liberalization are misstated if they are attributed solely to the change in trade policy. Rather, trade reform interacts with taxes to produce welfare changes that can be larger or smaller than the pure liberalization effects. Moreover, the gains from trade liberalization depend on the structure of distortionary taxes and whether such taxes are subject to reform as well. These interactions rarely have been analyzed explicitly in applied general-equilibrium models of trade reform, though distortionary taxes have appeared as exogenous policy variables in some openeconomy models (Whalley, 1985; Bizer and Stuart, 1987) or have been allowed to vary endogenously after trade liberalization (Keyzer, 1986; Rutherford, et al, 1993). ${ }^{1}$ Tax interactions have recently received attention in the context of environmental levies (Bovenberg and Goulder, 1996; Bovenberg and van der Ploeg, 1994; Goulder, 1995).

Our purpose in this paper is to investigate the importance of these interactive effects with a computable general equilibrium (CGE) model of trade liberalization developed for Egypt (Konan and Maskus, 1996). In the model we simulate a number of different potential trade reform measures in Egypt, including tariff unification, a free trade agreement (FTA) with the European Union, and unilateral free trade on a global basis. We perform these simulations against an idealized backdrop of lump-sum taxation and against the existence of two types of intersectorally distortionary taxes, one on capital use and one on consumption of commodities. Next, these taxes are subject to reform (unification) in all simulations, allowing a comparison of welfare impacts. A key element of the approach is to allow the tax instruments to vary endogenously within the model to replace lost government revenues when trade is liberalized or taxes are reformed.

With this technique, we are able to decompose total welfare changes from policy reform into a pure trade-reform effect, a tax-reform effect, and an interaction term representing the joint inefficiencies of the two regimes. In the next section we present a two-sector, two-factor general-equilibrium model of trade liberalization in the presence of distortionary taxes in order to illustrate the principles involved. In the third section we discuss the Egyptian model in terms of assumptions, data, dimensions, and parameters. In 
the fourth section we perform the simulations of trade policy and the associated decompositions. In general, we find that welfare gains from pure trade liberalization are comparable in magnitude to gains available from tax reform, while endogenous responses in tax rates can increase or decrease welfare. We provide concluding comments in the final section.

\section{The Two-Sector, Two-Factor Model of Taxes and Tariffs}

Consider a small open economy with two final goods, importables (M) and exportables (X). Assume that importables are capital-intensive and exportables are laborintensive. Both goods are produced with constant-returns production functions under conditions of perfect competition. Utility is additively separable between private consumption and a fixed amount, determined by social preferences, of a public good. The public good is financed via tariff revenues and other revenues from domestic taxes. Assuming that its price is fixed in terms of the numeraire good, there will be a constant revenue target. We use this model simply to illustrate concepts; the computable model is far more complicated as will be discussed in the next section.

The basic model is depicted in Figure 1, where there is an undistorted production frontier, labelled $\mathrm{F}_{0}$, between goods $\mathrm{X}$ and $\mathrm{M}^{2}$ The country faces fixed relative international prices $\mathrm{P}^{*}$, inducing production at $\mathrm{Q}_{0}$ and consumption at $\mathrm{C}_{0}$. An ad valorem tariff at rate $\tau$ drives a wedge between domestic and world prices such that $\mathrm{P}^{\mathrm{d}}=(1+\tau) \mathrm{P}^{*}$. Production moves to $\mathrm{Q}_{0}{ }^{\tau}$ and consumption to $\mathrm{C}_{0}{ }^{\tau}$, with a reduced trade volume, while trade is balanced at world prices. In this case, if the tariff is removed, the economy moves to the free-trade equilibrium $\left(\mathrm{Q}_{0}, \mathrm{C}_{0}\right)$ and the welfare gain is a pure trade-liberalization effect.

Suppose the economy has uniform tax rates on capital use in the two sectors. In a closed economy the output mix must satisfy the demand-determined equilibrium at a point on the frontier. Accordingly, the only response to the uniform tax is to change factor prices, with the capital price falling and the wage rate rising. Similarly, in a small open economy the producer equilibrium remains at point $\mathrm{Q}_{0}{ }^{\tau}$, by virtue of the fixed world price ratio and tariff rate. Accordingly, for any uniform capital tax rates, there must be a sufficient change in factor prices to support this equilibrium. In terms of comparative statics, for a given tariff a rise in the capital-tax rate alters real factor prices. The higher is the tax, the lower is the return to capital. However, for a given tax rate a tariff cut would move the economy along the frontier, with a movement upward corresponding to a rise in the real wage and a fall in the real capital return. ${ }^{3}$

Now suppose the economy has differential tax rates on capital use and that the tax on capital in exportables is higher than the capital tax on importables: $t_{x}>t_{m}$. These differential taxes push the economy off its undistorted PPF and onto a lower one, labelled $\mathrm{F}_{1}$. The reason is that the taxes drive a wedge between the ratios of marginal labor and capital products in the two sectors. So long as both goods are produced, the higher is the ratio $t_{x} / t_{m}$, the larger is this wedge and the further in the PPF must shrink as a result of the distortion. 
It is straightforward to show that the slope of the distorted frontier is:

$$
\frac{d X}{d M}=-\left|\frac{P_{M}}{P_{X}}\right| \frac{w+\left(1+t_{X}\right) r \frac{d K_{M}}{d L_{M}}}{w+\left(1+t_{M}\right) r \frac{d K_{M}}{d L_{M}}} 1
$$

Because $t_{X}>t_{M}$, it follows that $d X / d M>P_{M} / P_{X}$ in absolute value. Accordingly, the production equilibrium involves production on the shrunken PPF at a point where the absolute slope of the frontier exceeds the domestic price ratio. We show this equilibrium at point $\mathrm{Q}_{1}{ }^{\mathrm{t}}$. Trade must be balanced at world prices, implying a final consumption equilibrium at point $\mathrm{C}_{1}{ }^{\mathrm{t}}$.

Now consider trade liberalization. In this framework, the first-best policy is to remove the tariff and also to convert the capital taxes into a non-distortionary lump-sum tax, which may be set at whatever level is required to replace the lost tariff revenues. The tax conversion would move the economy onto the undistorted PPF, while the tariff removal would add the standard welfare gain from trade liberalization. It would be a mistake to ascribe the full welfare gain to trade liberalization alone.

In applied settings the ideal lump-sum tax instrument is unavailable and the government may be constrained to retain the capital taxes. If the government does not adjust the capital tax rates during trade liberalization, the economy would remain on frontier $\mathrm{F}_{1}$ as production equilibrium shifts to point $\mathrm{Q}_{2}$, where the absolute slope of the PPF still must exceed the world price ratio. Consumption equilibrium shifts to $\mathrm{C}_{2}$ at world prices. (Point $\mathrm{C}_{2}$ may involve higher or lower welfare than point $\mathrm{C}_{0}{ }^{\tau}$.) Of interest here is that the welfare gain from point $\mathrm{C}_{1}{ }^{\mathrm{t}}$ to point $\mathrm{C}_{2}$ may fairly be described as a pure trade liberalization gain, conditional on the unchanged capital tax rates.

However, because outputs, and therefore capital usages, have shifted between sectors, there is now a different level of capital tax revenues generated and a sub-optimal level of the public good. A change in tax policy is required to neutralize this effect. The total tax revenues generated in any equilibrium are:

$$
R=\tau\left(C_{M}-Q_{M}\right)+\frac{r}{P_{M}}\left(t_{X} K_{X}+t_{M} K_{M}\right) 2
$$

The first term represents real tariff revenues and the second term represents real capital-tax revenues. Tariff removal eliminates tariff revenues. Thus, the issue is whether revenues from the capital taxes rise by more or less than the reduction in tariff revenues. The precise impacts would depend on the structure of production functions. However, a qualitative prediction is available. The Stolper-Samuelson theorem guarantees that the ratio $r / \mathrm{P}_{\mathrm{M}}$ falls if good $\mathrm{M}$ is capital-intensive, as we have assumed. Further, the full-employment constraint that $\mathrm{dK}_{\mathrm{X}}=-\mathrm{dK}_{\mathrm{M}}$, in conjunction with the fact that $\mathrm{t}_{\mathrm{X}}>\mathrm{t}_{\mathrm{M}}$, implies that the term inside the parentheses rises. In short, the impact of tariff removal on real capital-tax revenues is ambiguous. On the one hand, the real price of capital falls but, on the other hand, capital use rises in the higher-tax sector.

Thus, the government would be expected to change tax rates to maintain constant real revenues. The ideal outcome, subject to fixed capital-tax rates, is a lump-sum tax for replacement, which would generate the equilibrium depicted at point $\mathrm{C}_{2}$. Again, however, 
this solution is unlikely to be practical, mandating a change in the capital taxes.

One possibility is to change tax rates differentially, which would alter the tax proportion $t_{\mathrm{X}} / \mathrm{t}_{\mathrm{M}}$. We maintain the assumption here (and in our CGE model) that the government chooses to raise or lower tax rates in proportion, keeping a constant ratio between them. ${ }^{4}$ In this context, the PPF remains static at $F_{1}$. If tax rates are reduced because endogenous revenues rise more than tariff revenues fall, the economy would tend to move to a production point above $\mathrm{Q}_{2}$, raising welfare further at fixed world prices. In the event that tax rates must be raised, the economy would tend to move to a production point such as $\mathrm{Q}_{3}$, meaning that the tax increases blunt the resource movement from trade liberalization. Such movements along the frontier are feasible in an open economy, even with a fixed international price ratio, because the follow-on rise in the proportional tax increases the effective wedge between ratios of marginal products. The higher tax rate also reduces the capital price and raises the wage rate.

Consider the measurement of welfare changes in these various cases. We adopt equivalent variations in real national income at fixed world prices as our measure. Thus, imagine extending each world price line to the $M$ axis. Consumption points $C_{0}, C_{2}$, and $C_{3}$ are tangencies to world price lines. Points $\mathrm{C}_{0}{ }^{\tau}$ and $\mathrm{C}_{1}{ }^{t}$ are on indifference curves tangent to domestic price lines, however, so that national-income measures should emanate from implicit tangencies of those indifference curves to world prices.

In this context, the maximum potential income gain would come from tariff removal and replacement of the capital taxes with a lump-sum tax, holding aggregate revenues constant. This would be represented by the movement from the tangency to $\mathrm{P}^{*}$ along the indifference curve through $\mathrm{C}_{1}{ }^{\mathrm{t}}$ to point $\mathrm{C}_{0}$. It would be a mistake to attribute this full gain to trade liberalization alone. If, instead, the policy were to replace the capital taxes with a lump-sum tax but not to liberalize trade, the economy would move from $\mathrm{C}_{1}{ }^{\mathrm{t}}$ to $\mathrm{C}_{0}{ }^{\tau}$. It is interesting to note that conversion to the lump-sum tax is not necessary for this outcome; if a uniform capital tax rate were adopted instead, the economy would move out to the undistorted production frontier.

This discussion suggests that the maximum potential gain from joint policy reform may be decomposed into a tax-reform gain $\left(\mathrm{C}_{1}{ }^{\mathrm{t}}\right.$ to $\left.\mathrm{C}_{0}{ }^{\tau}\right)$ and a further trade-liberalization gain $\left(\mathrm{C}_{0}{ }^{\tau}\right.$ to $\left.\mathrm{C}_{0}\right)$. However, the efficiency costs of tariffs and capital taxes are not independent. Rather, they interact in generating the full excess burden of the system. For example, a differentially higher (lower) capital tax on exportables raises (lowers) domestic output of importables, worsening (reducing) the distortionary impact of a given tariff (Rousslang, 1987). Stated differently, tax reform alone could generate some of the gains available from tariff reform, and vice-versa. These interactive impacts could moderate or exacerbate the efficiency costs of taxes and tariffs considered separately. Because they disappear in the event of joint policy reform, an interaction term must be computed in decomposing the full welfare effects.

As discussed earlier, complete tax reform may not be part of the policy package. It is conceivable that the government could adopt partial tax reform, in which capital taxes are 
equalized on some, but not all sectors. Depending on the tax structure and how it is altered, the impact of partial reform would be to move the production frontier outward or inward from $F_{1}$. The welfare effects of such a change should also be separated from tradeliberalization impacts.

Consider trade reform alone, with no change in tax policy. This would be represented by a movement from a production equilibrium at $\mathrm{Q}_{1}{ }^{\mathrm{t}}$ and consumption equilibrium $\mathrm{C}_{1}{ }^{\mathrm{t}}$ to a free trade equilibrium with production at $\mathrm{Q}_{2}$ and consumption at $\mathrm{C}_{2}$. The change in welfare accompanying a move from $\mathrm{C}_{1}{ }^{\mathrm{t}}$ to $\mathrm{C}_{2}$ may be thought of as a pure trade liberalization gain conditional on no change in the underlying capital tax structure. Again, however, liberalization results in a both a loss of tariff revenues and a change in capital tax revenues. Optimal provision of the public good requires an offsetting adjustment in the tax structure. Equilibrium remains undisturbed if these taxes are lump-sum in nature but if this adjustment entails a proportional increase (decrease) in the capital-tax rates, output would shift along $\mathrm{F}_{1}$ toward more $\mathrm{M}$ (more $\mathrm{X}$ ). The national-income line would be lower (higher) than that through point $\mathrm{Q}_{2}$. In the diagram, final equilibrium results at production point $\mathrm{Q}_{3}$ and consumption point $\mathrm{C}_{3}$, after an endogenous rise in capital taxes. Indeed, it is possible that welfare could fall with tariff removal. In this context, the true welfare gain from trade liberalization is the movement from $\mathrm{C}_{1}{ }^{t}$ to $\mathrm{C}_{2}$, which is simply a component of the full welfare movement, conditional on the tax structure, from $\mathrm{C}_{1}{ }^{\mathrm{t}}$ to $\mathrm{C}_{3}$. Typically, applied analysis would report the trade-liberalization income gain as the distance either only to point $\mathrm{C}_{3}$, which is inadequate, or to point $\mathrm{C}_{2}$ without recognizing that the latter outcome requires higher non-distortionary taxes or alters provision of the public good.

An alternative taxation possibility, that of a differential consumption (commodity) tax, is also considered in Figure 1. Suppose there is a higher tax on domestic consumption of good $\mathrm{M}$ than on consumption of good $\mathrm{X}$ (foreign consumers of the country's exports cannot be taxed with this instrument). In this case, the consumer price ratio, $\mathrm{P}^{\mathrm{ct}}$, exceeds the producer price ratio, $\mathrm{P}^{\mathrm{d}}$, which itself is tied to the world price ratio through the tariff. Accordingly, production equilibrium is at $\mathrm{Q}_{0}{ }^{\tau}$, consumption equilibrium is at $\mathrm{C}_{0}{ }^{\mathrm{ct}}$, and trade is balanced at world prices. Here, removal or unification of the commodity tax, holding the tariff fixed, would produce a welfare gain from $\mathrm{C}_{0}{ }^{\mathrm{ct}}$ to $\mathrm{C}_{0}{ }^{\tau}$ (in equivalent variation terms, this gain would be measured by the real national income gain in moving from a point along a world price line tangent to the indifference curve through $\mathrm{C}_{0}{ }^{\text {ct }}$ up to a similar tangency along the indifference curve through $\mathrm{C}_{0}{ }^{\tau}$ ). Subsequent tariff liberalization would yield additional gains to point $\mathrm{C}_{0}$. It is interesting to note that both solutions are independent of whether replacement tax revenues are raised through the commodity tax (so long as it is unified) or the lump-sum tax. Alternatively, the economy could remove the tariff, holding the distorted tax rates fixed. In this case, production equilibrium would move to point $\mathrm{Q}_{0}$, while because the consumer price ratio would become flatter to maintain a constant wedge with the producer price ratio, consumption equilibrium would emerge at a point, such as $\mathrm{C}_{2}$, , along the highest world price line. Welfare could be higher or lower than in the taxreform case alone. 
Finally, the economy could begin in a situation with both distorted capital and commodity taxes in place, which is depicted as point $\mathrm{C}_{1}{ }^{\mathrm{ct}}$ in Figure 1. Trade liberalization could be accompanied by no tax reform (yielding a consumption equilibrium on the price line through $\mathrm{Q}_{2}$ or $\mathrm{Q}_{3}$ with a lower consumer price ratio), capital-tax reform (yielding a consumption equilibrium at $\mathrm{C}_{2}{ }^{\mathrm{ct}}$ ), commodity-tax reform (yielding a consumption equilibrium at $\mathrm{C}_{2}$ or $\mathrm{C}_{3}$ ) or reform in both taxes (yielding the full liberalization outcome at $\left.\mathrm{C}_{0}\right)$.

The CGE model is capable of calculating requisite changes in both non-distortionary (lump-sum) taxes and distortionary taxes to offset any changes in budget revenues from tax reform and trade liberalization. Accordingly, we report a series of welfare decompositions associated with partial or complete tax reform (allowing for capital and commodity taxes separately or in combination), partial or complete trade reform, a combination of the two, and endogenous revenue replacements.

\section{The Computable General Equilibrium Model}

We model Egypt as a small open economy (SOE) that trades differentiated goods and services with multiple regions. In the model there are 38 sectors producing outputs, each using production and non-production labor, capital, and intermediate inputs. The sectors include three in agriculture, two in mining and quarrying, 21 in manufacturing, and 12 in services. They are listed in Table 1, along with acronyms we use in the simulation exercises. Production exhibits constant returns to scale and firms operate in a perfectly competitive environment, so that prices equal marginal output costs. The model is presented schematically in Figure 2.

The nested equations of the production block are as follows. First, there is a CES aggregator in each sector of production labor $\left(\mathrm{L}_{1}\right)$ and non-production labor $\left(\mathrm{L}_{2}\right)$ :

$$
\mathrm{L}_{\mathrm{i}}=\left[\mathrm{b}_{1 \mathrm{i}} \mathrm{L}_{1 \mathrm{i}}{ }^{(\mathrm{sL}-1) / \mathrm{sL}}+\mathrm{b}_{2 \mathrm{i}} \mathrm{L}_{2 \mathrm{i}}{ }^{(\mathrm{sL}-1) / \mathrm{sL}}\right]^{\mathrm{sL} /(\mathrm{sL}-1)}
$$

while value added is produced with a CES function of aggregate labor and capital:

$$
\mathrm{V}_{\mathrm{i}}=\left[\mathrm{a}_{\mathrm{Li}} \mathrm{L}_{\mathrm{i}}^{(\mathrm{si}-1) / \mathrm{si}}+\mathrm{a}_{\mathrm{Ki}} \mathrm{K}_{\mathrm{i}}^{(\mathrm{si}-1) / \mathrm{si}}\right]^{\mathrm{si} /(\mathrm{si}-1)}
$$

Imported intermediate inputs of each commodity are aggregated into a CES composite import $\left(\mathrm{M}_{\mathrm{iN}}\right)$, allowing substitution possibilities across regional supply sources ( $\mathrm{r}$ ) of imports, according to the Armington elasticity $\mathrm{s}_{\mathrm{i}}$ :

$$
\mathrm{M}_{\mathrm{iN}}=\left[\mathrm{S}_{\mathrm{r}} \mathrm{d}_{\mathrm{ri}} \mathrm{m}_{\mathrm{riN}}{ }^{(\mathrm{si}-1) / \mathrm{si}}\right]^{\mathrm{s} /(\mathrm{si}-1)}
$$

Intermediate use of good $\mathrm{j}$ in sector $\mathrm{i}$ is a CES composite (z) of domestic and imported sources:

$$
\mathrm{z}_{\mathrm{ji}}=\left[\mathrm{g}_{\mathrm{di}} \mathrm{d}_{\mathrm{ji}}^{(\mathrm{sj}-1) / \mathrm{sj}}+\mathrm{g}_{\mathrm{mi}} \mathrm{m}_{\mathrm{ji}}^{(\mathrm{sj}-1) / \mathrm{sj}}\right]^{\mathrm{sj} /(\mathrm{sj}-1)}
$$

Final output is produced as a Leontief function between value added (V) and intermediates: ${ }^{5}$

$$
\mathrm{Y}_{\mathrm{i}}=\min \left[\mathrm{z}_{1 \mathrm{i}} / \mathrm{a}_{1 \mathrm{i}}, \ldots, \mathrm{Z}_{\mathrm{ni}} / \mathrm{a}_{\mathrm{ni}}, \mathrm{V}_{\mathrm{i}} / \mathrm{a}_{\mathrm{VA}}\right]
$$

Output is split between domestic and foreign sales by a CET specification:

$$
Y_{i}=\left[a_{D i} D_{i}^{(e i-1) / e i}+a_{X i} X_{i}^{(e i-1) / e i}\right]^{\mathrm{e} /(e i-1)}
$$

while the allocation of exports across destination regions depends on an Armington 
elasticity of transformation:

$$
\mathrm{X}_{\mathrm{i}}=\left[\mathrm{S}_{\mathrm{r}} \mathrm{b}_{\mathrm{ri}} \mathrm{X}_{\mathrm{ri}}{ }^{(\mathrm{ei}-1) / \mathrm{ei}}\right]^{\mathrm{ei} /(\mathrm{ei}-1)}
$$

Finally, we impose the following condition defining marginal cost and implicitly embedding profit-maximization:

$$
c_{\mathrm{i}} Y_{\mathrm{i}}=\mathrm{S}_{\mathrm{j}} \mathrm{p}_{\mathrm{j}} \mathrm{d}_{\mathrm{ji}}+\mathrm{S}_{\mathrm{j}} \mathrm{S}_{\mathrm{r}}\left(1+\tau_{\mathrm{rj}}\right) \mathrm{p}_{\mathrm{rj}}{ }^{\mathrm{m}} \mathrm{m}_{\mathrm{rji}}+\mathrm{S}_{\mathrm{i}}\left(1+\mathrm{t}_{\mathrm{Ki}}\right) \mathrm{w}_{\mathrm{Ki}} \mathrm{K}_{\mathrm{i}}+\mathrm{w}_{\mathrm{L} 1} \mathrm{~L}_{1 \mathrm{i}}+\mathrm{w}_{\mathrm{L} 2} \mathrm{~L}_{2 \mathrm{i}}
$$

In equation (10), $\tau_{\mathrm{rj}}$ indicates the tariff rate on imports of intermediate good $\mathrm{j}$ from region $\mathrm{r}$, while $t_{\mathrm{Ki}}$ indicates the rate of capital tax in sector $\mathrm{i}$. The terms $\mathrm{p}_{\mathrm{j}}$ and $\mathrm{p}_{\mathrm{rj}}{ }^{\mathrm{m}}$ are prices of domestic and imported commodities, while wages are indexed by $\mathrm{w}_{\mathrm{L} 1}$ and $\mathrm{w}_{\mathrm{L} 2}$.

Turning to the demand side of the model, we assume a single household is representative of a domestic consumer. The consumer seeks to maximize utility as characterized by a nested CES function with a corresponding multi-staged budget process. In the first stage, the consumer decides how much to spend on goods from each sector in a Cobb-Douglas utility nest:

$$
\mathrm{U}=\mathrm{P}_{\mathrm{i}} \mathrm{C}_{\mathrm{i}}^{\mathrm{li}} ; \mathrm{S}_{\mathrm{i}} \mathrm{I}_{\mathrm{i}}=1
$$

In the second nest, the consumer determines domestic and aggregate import expenditures in each sector according to a CES function:

$$
C_{i}=\left[f_{D i} D_{i C}{ }^{(y i-1) / y i}+f_{M i C} M_{i C}^{(y i-1) / y i}\right]^{y i /(y i-1)}
$$

Finally, given a budget for imports the consumer selects purchases from each region in a CES nest:

$$
\mathrm{M}_{\mathrm{iC}}=\left[\mathrm{S}_{\mathrm{r}} \mathrm{d}_{\mathrm{ri}} \mathrm{M}_{\mathrm{ric}}{ }^{(\mathrm{si}-1) / \mathrm{si}}\right]^{\mathrm{s} /(\mathrm{si}-1)}
$$

We assume that equations (12) and (13) also characterize the split of government consumption and investment spending between domestic and imported goods and services. The representative consumer receives income from primary factors, net transfers from the government, and the current-account deficit. Thus, the agent's budget constraint is:

$$
\Sigma_{\mathrm{i}} \mathrm{pi}^{\mathrm{C}} \mathrm{C}_{\mathrm{i}}=\mathrm{S}_{\mathrm{i}} \mathrm{W}_{\mathrm{Ki}} \mathrm{K}_{\mathrm{i}}+\mathrm{w}_{\mathrm{L} 1} \mathrm{~L}_{1}+\mathrm{w}_{\mathrm{L} 2} \mathrm{~L}_{2}+\mathrm{eB}-\Sigma_{\mathrm{i}} \mathrm{p}_{\mathrm{i}} \mathrm{IF}_{\mathrm{i}}{ }^{\mathrm{F}}-\mathrm{S}_{\mathrm{i}} \mathrm{p}_{\mathrm{i}} \mathrm{I}_{\mathrm{i}}^{\mathrm{I}}-\mathrm{D}
$$

In this equation, $\mathrm{p}_{\mathrm{i}}^{\mathrm{C}}$ indicates the domestic price index (across home and import prices) of consumption. The term eB is the real current-account imbalance in Egyptian currency terms (see below), while $\mathrm{D}$ is the real government budget deficit. The representative agent also must pay for fixed capital formation $\left(\mathrm{Ii}^{\mathrm{F}}\right)$ and inventory investment $\left(\mathrm{I}_{i}^{\mathrm{I}}\right)$.

Further constraints and balancing items must be added to the model. The government budget constraint is:

$$
\begin{aligned}
& \Sigma_{\mathrm{i}} \mathrm{p}_{\mathrm{i}}^{\mathrm{G}} \mathrm{G}_{\mathrm{i}}=\mathrm{D}+\Sigma_{\mathrm{i}} \mathrm{t}_{\mathrm{Ki}} \mathrm{W}_{\mathrm{Ki}} \mathrm{K}_{\mathrm{i}}+\Sigma_{\mathrm{i}} \mathrm{t}_{\mathrm{Ci}}\left(\mathrm{p}_{\mathrm{i}}{ }^{\mathrm{C}} \mathrm{C}_{\mathrm{i}}+\mathrm{p}_{\mathrm{i}}{ }^{\mathrm{IF}} \mathrm{I}_{\mathrm{i}}^{\mathrm{F}}\right) \\
& +\mathrm{S}_{\mathrm{i}} \mathrm{S}_{\mathrm{r}}\left(1+\mathrm{t}_{\mathrm{Ci}}\right) \mathrm{t}_{\mathrm{ri}} \mathrm{p}_{\mathrm{ri}}{ }^{\mathrm{m}}\left(\mathrm{M}_{\mathrm{ri}}+\mathrm{M}_{\mathrm{ril}}{ }^{\mathrm{F}}\right)
\end{aligned}
$$

This constraint incorporates taxes on capital use and commodity consumption, the latter being imposed on consumption of goods and services from both domestic and foreign sources. The definition of the current-account imbalance is:

$$
\mathrm{B}=\mathrm{S}_{\mathrm{r}} \mathrm{S}_{\mathrm{i}}(1 / \mathrm{e})\left(\mathrm{p}_{\mathrm{ri}}{ }^{\mathrm{m}} \mathrm{M}_{\mathrm{ri}}-\mathrm{p}_{\mathrm{ri}}{ }^{\mathrm{x}} \mathrm{X}_{\mathrm{ri}}\right)
$$

Note that we treat consumers and producers as agents that optimize in a single time period. The equilibrium solutions are inherently static as decision-making is not based on a model of intertemporal optimization. This assumption of static equilibria informs linkages among the representative agent's budget constraint, the government budget constraint, and 
the current-account imbalance. The capital stock is assumed to be exogenously fixed at the benchmark level. This stock is financed through forced consumer savings that act as a direct (lump-sum) tax. A capital good is modelled as composite goods of fixed composition. Firms buy composite capital according to their preferences. The interest rate (an index price of the composite capital stock) is endogenous and determined by factor demand conditions. We do not distinguish between domestic capital and capital inflows from foreign direct investment (FDI). That trade liberalization could affect the volume of FDI is clear, but the direction of influence is ambiguous. Determinants of FDI are beyond the scope of this analysis.

Regarding the balance of payments, we hold the current-account imbalance fixed at its benchmark level throughout the simulations. Foreign currencies are scaled so that the appropriate GDP deflator ("world" price index) is one. In keeping with our small-economy assumption, we maintain a fixed world price index throughout the analysis. Because the current account is in deficit in Egypt, it represents an addition to the agent's income through exogenous capital inflows, as noted in equation (14). To hold B fixed while international prices are constant requires a balancing item in equation (16). This is accomplished by means of a change in the home "real exchange rate", which refers implicitly to a change in the home price index (generated by changes in price of home-produced goods) sufficient to sustain a constant current-account deficit measured at world prices. ${ }^{6}$ Thus, B is held fixed, along with the price terms, requiring e to change as import and export volumes change.

The government budget deficit is a deduction in available income for the representative agent, constituting a transfer to government consumption. As indicated earlier, we hold D fixed during our simulations. Regarding expenditures, we assume that the government chooses to consume an unchanged bundle of goods and services throughout all scenarios. Thus, if a policy reform causes prices to fall, thereby reducing the tax revenues required to finance this bundle, the tax saving is transferred to the agent. At the same time, if trade liberalization results in lost tariff revenues, the revenues are recouped by allowing tax rates to vary.

There are three tax instruments. First is an average sales tax rate, $t_{C i}$, which varies across goods in the economy. Second is a tax, $\mathrm{t}_{\mathrm{Ki}}$, on capital, which is defined as operating surplus plus depreciation. The final tax is a lump-sum replacement tax, which does not appear in the equations above but is implicit in the calculation of the fixed deficit D.

The model is completed by incorporating equations for product-market clearance, factor-market clearance, zero-profit conditions, a series of price relationships incorporating tariffs and taxes, and a condition ensuring balance in the aggregate value of sectoral supplies.

The data for the Egyptian model consist of a Social Accounting Matrix (SAM) and other parameters, such as elasticities of substitution and transformation, import and export trade flow shares by region, and tax and tariff rates. The data are assembled into a consistent set of relationships among intermediate demand, final demand, and value added for the initial benchmark year 1990. We use the 1989/1990 input-output table for Egypt, 
which includes the production sectors in Table 1. Note in Column (1) that the largest output shares are in vegetable food products, animal products, food processing, trade, transport, social services, construction, and cotton textiles. The remainder of the table shows sectoral shares of total employment and capital and of total imports and exports. Despite their relatively large presence in production, vegetable foodstuffs and food processing are major import goods, as are machinery and chemicals. On the export side, Egypt's trade flows are dominated by transport (due to the Suez Canal), oil, and textiles.

The 1990 input-output table showed indirect taxes and subsidies levied on production. These net indirect tax rates varied dramatically across sectors and simulations with the 1990 benchmark figures indicated that this situation was highly distortionary. Egypt modified this tax structure considerably by 1993, phasing in a new goods and services tax (GST) and phasing out indirect production taxes and subsidies. The GST has a complicated structure and is applied on sales of goods and services at various rates. The rates, which are listed in Table 2, vary from $0.0 \%$ in food products, paper, petroleum refining, and insurance to $25.0 \%$ in many luxury and investment goods, such as machinery and transport equipment. The standard tax rate is $10.0 \%$. Taxes paid by firms on their intermediate inputs are recoverable through a tax credit, suggesting that the tax operates as a value-added tax. However, such credits are not available for purchases of investment goods and some service inputs. Absent sufficient information on these tax credit exceptions, we model the tax as a levy solely on final goods purchases, assuming that taxes on all inputs are credited back to purchasing firms. The GST applies to imports, consumption, and investment in capital goods and structures. It does not apply to exports and we assume that it does not apply to government purchases (including imports) and inventory investment.

Also listed in Table 2 are effective corporate tax rates on capital use. These rates are considerably lower than legislated rates, reflecting tax holidays, depreciation schedules, and various exemptions. There is no tax on agriculture, a $23 \%$ effective tax on services, and an $18 \%$ tax on manufactures. The statutory rate underlying the effective rate in manufacturers is meant to apply to all commodities other than agriculture, so we apply the effective tax also to the mining and crude oil sectors. We incorporate these rates into the 1990 SAM, using them to calibrate the initial benchmark economy.

We also report 1994 tariff rates aggregated to the input-output basis. Egypt does not realize full revenue on its legislated tariffs because of various exemptions for dutydrawback provisions, investment incentives, and performance requirements. We therefore scale the weighted legal tariff rates downward approximately $20 \%$ in order to be consistent with total import duty collections in 1994. We take the effective tariff rates on services to be $15 \%$ to capture the likelihood that trade liberalization would reduce effective barriers to services trade.

Columns (4) and (5) of Table 2 provide import and export shares in 1994 for the EU (including Turkey) in Egypt's trade. We incorporate these shares in light of our interest in regional trade preferences and their interaction with other distortions in the model. Merchandise trade shares are aggregated from the 8-digit Harmonized System 
classification. Egypt's merchandise trade structure is strongly diversified on a regional basis. For example, the EU's share of both Egyptian merchandise imports and exports is around $45 \%$. This indicates that there is considerable potential for trade diversion from a preferential trade agreement. Unfortunately, there are no data available on services trade in 1994 or on its breakdown by regions. Accordingly, we assume that services trade is closely complementary to merchandise trade in terms of its sources. Therefore, the EU shares of services trade are set equal to its share in total imports or exports of merchandise.

The model is initially benchmarked to the 1990 data set, including taxes and tariffs. Before performing the various trade-liberalization exercises, the model is updated from the 1990 benchmark to the tax and tariff structure as of 1994. To implement this exercise we update the SAM with information on policy reforms since 1990, including the introduction of the GST, the elimination of indirect taxes, and tariff reform. As noted earlier, the new tariff rates are scaled to match 1994 revenue collections. However, the GST rates are taken as listed in Table 2, with an adjustment to make them revenue neutral. In other words, implied total collections under the reformed 1994 GST system are adjusted to be consistent with the real value of the 1990 government budget deficit. We assume that the sectoral share of government consumption does not change as a result of the tax shift.

To implement all of these reforms in the updated 1994 database, we achieve tax neutrality by proportionately scaling a tax-replacement instrument (rates of the consumption tax itself, the capital taxes, or the level of a lump-sum tax). Thus, the 1994 updated benchmark equilibrium, against which we calculate the implications of various trade-policy changes, is kept fiscally neutral in the macroeconomy. In the absence of an input-output table and SAM for 1994, we assume that the 1990 SAM adequately represents production technologies and preferences for the later year.

Elasticities are required for substitution between primary factors, labor types, import and domestic demand, and regional import sources. Transformation elasticities are needed for domestic supply into domestic and foreign markets and across regional exports. There is scant empirical evidence about Egyptian elasticity parameters. We follow Rutherford, et al (1993) in selecting the benchmark elasticities. Labor-capital substitution varies across sectors, ranging from 0.43 to 1.99, as taken from Harrison, et al (1993). Labor-labor substitution is set at 0.5 to be conservative in this parameter. The various trade substitution elasticities are equal across sectors and are consistent with the ranges reported in Lofgren (1994). The substitution elasticity between domestic and imported goods (both intermediates and consumption) is set at 2.0. The Armington elasticity between regional imports is taken to be 5.0, as is the transformation elasticity between domestic and exported output. The transformation elasticity between regional exports is set at 8.0. ${ }^{7}$ Systematic sensitivity analysis on these parameters is performed in Konan and Maskus (1996).

\section{Simulation Results}

The CGE model we use is considerably more complicated than the two-sector, twofactor model discussed for heuristic reasons in Figure 1. Imported goods and domestic 
goods are not perfect substitutes, nor are domestic goods and exports. Rather, all products and services are characterized by an Armington assumption, causing them to be differentiated by source. Thus, while we use the insights of Figure 1 at times to motivate the ensuing discussion, welfare rankings of policy instruments do not necessarily correlate perfectly with the simple theory.

Tables 3-5 contain selected results from simulating reforms in the tax and tradepolicy systems. The variables reported include percentage change in economic welfare (measured in equivalent variation as a percentage of 1994 benchmark GDP), percentage change in the real exchange rate required to maintain a constant real current-account imbalance, percentage change in the rates of the consumption tax (GST) required for revenue neutrality, percentage change in the rates of the capital tax required for revenue neutrality, absolute change in the implicit lump-sum tax (measured in billions of real 1994 Egyptian pounds, or ELs) to maintain revenue neutrality, percentage change in the real wage of production workers, and percentage change in the real price of capital. ${ }^{8}$

In Table 3 we report results of simulating reforms in the tax system alone, without alteration to trade policies. In Panel One we remove the GST or unify its rate at $6.6 \%$ across sectors, maintaining the distorted structure of the capital tax, and replace lost revenues with endogenous changes in the various taxes, as indicated in scenarios (A) through (E). ${ }^{9}$ The choice of removal or unification is important. For example, removing the GST results in lost revenue, so that offsetting this with greater use of the distorted capital tax (column (A)) generates lower welfare and a lower capital price. Intuitively in terms of Figure 1, GST removal subject to the distorted capital tax moves the economy from point $\mathrm{C}_{1}{ }^{\text {ct }}$ to point $\mathrm{C}_{1}{ }^{\mathrm{t}}$ but then the higher tax rates move production in the economy down and to the right along frontier $F_{1}$, reducing welfare overall. However, unification of the GST generates higher revenues (itself an indication of the inefficiency of the GST), so that the endogenous reduction in the capital tax (column (D)) procures higher welfare and a rise in the price of capital. Stated in other terms, the capital tax is so distortionary that its endogenous reduction markedly raises welfare. In this case the economy moves up $\mathrm{F}_{1}$ and ends at a point between $\mathrm{Q}_{3}$ and $\mathrm{C}_{3}$.

The other three cases are equivalent in terms of welfare because a unified (or zero) consumption tax and a lump-sum tax are identical instruments for the representative agent. They are not the same in terms of their effects on the real exchange rate or real factor prices, however. For example, removal of the GST with a higher lump-sum tax (column (B)) sufficiently increases economic efficiency to raise both factor prices. Unification of the tax with a lower lump-sum tax (column (E)) reduces both factor prices, however. The primary difference is that in the former case the Egyptian currency depreciates in real terms and in the latter case it appreciates. Note that removal of the GST tends to depreciate the pound, suggesting that the GST itself limits import demand.

Capital tax reform is summarized in Panel Two. Because the GST remains distorted, it is not equivalent to the lump-sum tax in welfare terms. Removal of the capital tax raises welfare by $0.43 \%$ to $0.82 \%$, with a large increase in real returns to capital (columns (A) and 
(B)). Heuristically, this removal shifts the economy out to frontier $F_{0}$ in Figure 1, inducing a movement from point $\mathrm{C}_{1}{ }^{\text {ct }}$ to point $\mathrm{C}_{0}{ }^{\text {ct }}$. In case (A) the follow-on rise in GST rates generates a bigger price wedge between consumer and producer prices, moving the economy back toward $\mathrm{F}_{0}$ along the price line. In case $(\mathrm{B})$ the follow-on rise in lump-sum taxation does not induce this additional distortion. Note that removal of the capital tax tends to appreciate the pound, suggesting that the tax is biased against exports. The remaining three cases consider unification of the capital tax rates at $13.6 \%$, which has much smaller impacts on the capital price. ${ }^{10}$ With a unified capital tax, revenue replacement with either that tax or the lump-sum tax are equivalent in welfare terms, though they have different effects on the real capital price. That the lump-sum replacement rule in case (E) results in a lower welfare gain than the GST replacement rule in case (C) reflects the fact that in the latter case there is a follow-on reduction in distortionary consumption taxes. This reduces their excess burdens in the economy by more than the gain in welfare from the lower transfer to the government in the lump-sum case.

Finally, in Panel Three we consider joint tax reforms. Whether the taxes are removed or unified, both become equivalent to lump-sum taxes for the agent in welfare terms, so that any package raises real welfare by $1.09 \%$. The main differences are that removal of the capital tax alone tends to appreciate the currency, raise the real return to capital, and reduce real wages. In terms of Figure 1, the case in column (E) is depicted by the increase in welfare from point $\mathrm{C}_{1}{ }^{\text {ct }}$ to point $\mathrm{C}_{0}{ }^{\tau}$. The strongest increases in real factor prices emerge from joint removal of both the GST and the capital tax.

Summarizing, it seems that Egypt could achieve up to a one-percent gain in welfare from reforming its tax system. Reforming only one tax would result in lower gains, while the forms in which reform take place are not neutral with respect to factor prices and the exchange rate.

Table 4 considers the impacts of trade-policy reforms alone, without changes in the tax system. Three reforms are considered. ${ }^{11}$ First, we unify tariff rates at $10 \%$ across all imports. $^{12}$ Second, we model a free-trade agreement (FTA) with the European Union, which is under active negotiation at this time. In our conception, Egypt eliminates all tariffs on EU imports while maintaining existing tariffs against other countries at current levels. The EU responds by providing to its domestic markets additional access sufficient to procure an eight-percent increase in the prices of Egyptian agricultural goods and textiles and apparel in the EU, along with a one-percent rise in prices of all other Egyptian goods there. The former assumption reflects the strong protection of agriculture and textiles in Europe, while the latter is designed to capture the benefits to Egypt from having the EU recognize Egyptian inspection practices, production standards, and the like. ${ }^{13}$ Finally, we consider full unilateral tariff elimination by Egypt against all trading partners, without simulating any export price rises.

In Panel One we indicate results of tariff reform. Unifying tariffs results in an increase in tariff revenue, allowing an endogenous fall in the other tax instruments. Again, the welfare gain from this change is largest for the capital-tax case, since it is highly 
distortionary. Panel Two shows results of the FTA. The results are similar, though welfare gains are lower, both because the FTA results in some trade diversion and because it generates smaller increases in tariff revenue. The FTA tends to raise all factor prices. Finally, in Panel Three we report the effects of full tariff liberalization by Egypt. This policy procures a gain in welfare of $0.89 \%$ in the case of a lump-sum replacement rule, a small depreciation of the real exchange rate, and an increase in all factor prices. In terms of Figure 1, eliminating tariffs would be captured by a movement of the production point from $\mathrm{Q}_{1}{ }^{\mathrm{t}}$ to a point such as $\mathrm{Q}_{2}$ and consumption from point $\mathrm{C}_{1}{ }^{\mathrm{ct}}$ to a point such as $\mathrm{C}_{2}$. However the follow-on increases in the GST or capital tax would induce additional distortions from that point. In the case of the lump-sum tax the welfare gain of $0.89 \%$ from trade liberalization may be compared to the welfare gain of $1.09 \%$ available from joint tax reform.

Table 5 indicates results from combining tax reform with trade-policy reform. There are many possibilities here, so we provide only an overview. In Panel One we simulate GST reform and the three types of trade reform, allowing all possible revenue replacement rules. Scenarios (A), (B), and (C) remove the GST and liberalize trade, while compensating for revenue losses with higher capital taxes. In each case Egypt would be worse off from such a package. The worst outcome is the FTA, which not only generates trade diversion but also dramatically raises rates of taxation on capital. In each case the return to capital falls. Columns (D), (E), and (F) remove the GST and liberalize trade, allowing for replacement with the idealized (and unavailable) lump-sum tax. In this case, tax reform and free trade (unilateral liberalization) together procure a gain in welfare of $1.21 \%$ of GDP, a substantial real depreciation of the pound, and a rise in all factor prices. The remaining columns unify the GST, with a variety of trade-liberalization scenarios and replacement rules. In each group of three trade-reform exercises, the FTA generates the smallest welfare gains. When the FTA is combined with capital tax replacement, the FTA reduces the available welfare gain (compare column (K) with column (D) in Panel One of Table 3).

In Panel Two we combine reform of the capital tax with trade reforms. In all scenarios, capital-tax reform raises real returns to capital, while the direction of impact on labor depends on circumstances. Interestingly, with removal of the capital tax and a GST replacement rule, tariff unification is better than free trade (compare columns (A) and (C)). The reason is that tariff unification requires smaller endogenous increases in distortionary GST rates. Largest welfare gains are available from removal of the capital tax, free trade, and revenue replacement with the lump-sum tax (column $(\mathrm{F})$ ), which together generate a $1.47 \%$ gain in welfare and a substantial rise in real capital returns. Referring to Figure 1, this case would be characterized by a shift out of the production frontier (the source of the increased capital price) and a movement up $\mathrm{F}_{0}$. Thus, production would move from $\mathrm{Q}_{1}{ }^{\mathrm{t}}$ to $\mathrm{Q}_{0}{ }^{\tau}$ and consumption from $\mathrm{C}_{1}{ }^{\mathrm{ct}}$ to $\mathrm{C}_{0}{ }^{\mathrm{ct}}$.

The remaining columns in Panel Two consider capital-tax unification in conjunction with trade reform. In scenarios $(\mathrm{G})$ and $(\mathrm{H})$, the distortionary GST rates decline, explaining the larger welfare gains than in their counterpart cases $(\mathrm{J})$ and $(\mathrm{K})$, with capital-tax 
replacement, and $(\mathrm{M})$ and $(\mathrm{N})$, with lump-sum replacement. However, lump-sum replacement in column $(\mathrm{O})$ (equivalent to capital-tax replacement in column $(\mathrm{L})$ in welfare terms) is superior to GST replacement in column (I) in the case of full trade liberalization. Overall, maximum gains of $1.47 \%$ of GDP are available from full trade liberalization and capital-tax reform. That this gain exceeds the maximum gain from GST reform of $1.21 \%$ of GDP (see column (O) of Panel One) attests to the greater inefficiency of the capital tax than the GST in conjunction with trade policy.

The results in Panel Three show joint reform of both tax systems and trade-policy change. In each column, the welfare gains available are highest in Panel Three, indicating that joint tax reform dominates single tax reform of any kind in the presence of trade liberalization. For reasons discussed earlier, the welfare impacts of each trade reform are the same, regardless of the type of joint tax reform (compare each set of three columns in Panel Three). The most efficient outcome for the economy resides in column (C), where both taxes are eliminated, the economy goes to free trade, and lost revenues are replaced with the (ideal) lump-sum tax. This joint simulation results in a welfare gain of $1.63 \%$ of GDP, a real depreciation of $1.99 \%$, and a sharp rise in all real factor prices. In principle, this outcome represents the fully efficient solution in Figure 1, with production at point $\mathrm{Q}_{0}$ and consumption at $\mathrm{C}_{0}{ }^{14}$

It is possible to use these computations to decompose the total welfare gains into an effect associated with tax reform, an effect associated with trade reform, and an interaction term. The interaction term reflects the fact that either reform alone will produce some gains that overlap those of the other reform. For example, consider an importable commodity that is subject to a tariff and a consumption tax levied on the tariff-inclusive domestic price. Removal of the tariff alone generates both a consumer-surplus gain and higher GST revenues produced by additional imports. Removal of the consumption tax alone generates a different consumer-surplus gain and higher tariff revenues. The sum of these effects double-counts some overlapping welfare gains and overstates gains from joint reform. However, there are net efficiency gains from joint reform that are unavailable from either individual policy change, implying that the interaction term could be positive or negative. ${ }^{15}$

We list in Panel One of Table 6 the decomposition from reforming both tax systems jointly, along with unilateral tariff liberalization. In the first column, the results indicate that removing or unifying both taxes would raise welfare by $1.09 \%$ of GDP. Trade liberalization alone would raise welfare by $0.89 \%$ of GDP. These do not sum to the total welfare gain of $1.63 \%$ because there are combined effects of the full tax system on economic efficiency. The taxes and tariffs interact to reduce the sum of their efficiency costs by $0.35 \%$, which gain disappears upon full policy reform. The remaining columns may be read in the same fashion. Nearly all the interaction terms are negative. In some cases the interaction effect is large. For example, in Panel Three, capital-tax reform combined with free trade but including GST revenue replacement produces a welfare gain of $0.68 \%$ of GDP. However, a larger gain is available solely from trade liberalization, while the tax reform alone results in a welfare gain of $0.48 \%$. In this case, there is a strong 
overlap in the impacts of the trade and tax regimes, which offsets markedly either regime's efficiency costs. Finally, in comparing the potential gains from policy reforms, there is no general suggestion that tax reform dominates trade reform or vice-versa. Both measures are important in procuring a more efficient economy for Egypt.

\section{Conclusions}

Applied general equilibrium analyses are rarely focused on the important interrelationships between trade policies and tax regimes. Rather, they tend to take one set of policies as given (or absent) and analyze the other. We have demonstrated, in the context of the Egyptian economy, that both types of distortions are important and that they interact in determining the efficiency costs of revenue-generating policies. Accordingly, trade liberalization in the face of distortionary taxes, maintaining a fixed revenue target, is liable

to produce markedly smaller welfare gains than is available from joint policy reform. This statement applies also to the impact of tax reform in the presence of trade restrictions. 


\section{Endnotes}

1. Of course, tax reform itself is the subject of many computational analyses in closed economies, such as Ballard, Shoven, and Whalley (1985).

2. Rousslang (1987) provides a partial-equilibrium diagrammatic analysis of import tariffs in the presence of excise and income taxes that also captures some of these effects.

3. One implication is that the tariff and capital tax cause a difference in home and foreign relative factor prices, which would induce international capital flows. We ignore this possibility here by assuming balanced commodity trade, while in our CGE model we hold constant the real value of international capital flows through maintaining a constant real current-account imbalance.

4. One justification for this assumption is that the sectoral structure of taxes depends on political-economy pressures and would be invariant to shifts in the average level of taxes.

5. We have also simulated the model with a CES specification between value added and intermediates, with no qualitative differences in results.

6. A more accurate interpretation is that the real exchange rate is the shadow price of foreign exchange (a "commodity") required to maintain a constant current-account imbalance. A rise in the real exchange rate is consistent with a depreciation of home currency, in that the per-unit price of foreign exchange rises.

7. Although the simulation results focus on a free trade agreement with the EU, other regions (the United States, middle East-North Africa, and the rest of the world) are included in the computations.

8. The model also simulates changes in wages of nonproduction workers, but we do not report those here since they are highly correlated with changes in wages of production workers. The full model is also capable of simulating short-term and medium-term impacts of tax and trade-policy changes by virtue of maintaining fixed and partially fixed capital stocks.

9. The unified GST rate of $6.6 \%$ is required to achieve revenue neutrality, holding fixed the initial (inefficient) factor uses and prices. This "first-step" reform generates a disequilibrium, causing factor reallocations in a second stage, which then generates a rise or fall in government revenues. At this stage the various tax instruments are allowed to change endogenously in order to maintain constant real revenues.

10. Again, the unified rate maintains constant revenues in the first stage. 
11. In Konan and Maskus (1996) several other trade-policy scenarios are entertained.

12. This is not a revenue-neutral change in tariffs, but is a realistic reform possibility for Egypt. Subsequent tax changes maintain constant real revenues. We prefer not to consider tariffs as a revenue-replacement instrument in order to separate trade reform from tax reform.

13. See Konan and Maskus (1996) for further discussion.

14. There are many other distortions in Egypt that we have not modelled, so this statement is a notional one.

15. This case is only illustrative. In the CGE model there are numerous interaction effects associated with imperfect commodity substitutability in demand and with domestic production decisions. 


\section{References}

Ballard, Charles L., John B. Shoven, and John Whalley (1985), "General Equilibrium Computations of the Marginal Welfare Costs of Taxes in the United States," American Economic Review, Vol. 75, No. 1, 128-138.

Bizer, David S. and Charles Stuart (1987), "The Public Finance of a Protective Tariff: The Case of an Oil Import Fee," American Economic Review, Vol. 77, No.5, 1019-1022.

Bovenberg, A. Lans and Lawrence H. Goulder (1996), "Optimal Environmental Taxation in the Presence of Other Taxes: General-Equilibrium Analyses," American Economic Review, Vol. 86, No. 4, 985-1000.

Bovenberg, A. Lans and Frederick van der Ploeg (1994), "Environmental Policy, Public Finance and the Labor Market in a Second-Best World," Journal of Public Economics, Vol. 55, No. 3, 349-390.

Goulder, Lawrence H. (1995), "Effects of Carbon Taxes in an Economy with Prior Tax Distortions: an Intertemporal General Equilibrium Analysis," Journal of Environmental Economics and Management, Vol. 29, No. 3, 271-297.

Harrison, Glenn W., R. Jones, Larry Kimbell, Jr., and Randy Wigle (1993), "How Robust Is Applied General Equilibrium Modelling?" Journal of Policy Modelling, Vol. 15, No. 1,99-115.

Keyzer, Michiel A. (1986), "Short-Run Impact of Trade Liberalization Measures on the Economy of Bangladesh: Exercises in Comparative Statics for the Year 1977," in T. N. Srinivasan and John Whalley, eds., General Equilibrium Trade Policy Modelling, (Cambridge: MIT Press), 251-282.

Konan, Denise and Keith E. Maskus (1996), "A Computable General Equilibrium Analysis of Scenarios for Trade Liberalization Using the Egypt CGE-TL Model," The World Bank, MENA Working Paper.

Lofgren, Hans (1994), "Elasticity Survey," mimeo, Center for Egyptian Studies, Cairo.

Rousslang, Donald J. (1987), "The Opportunity Cost of Import Tariffs," Kyklos, Vol. 40, No. $1,88-102$.

Rutherford, T., E.E. Rutstrom, and D. Tarr (1993), "Morocco's Free Trade Agreement with the European Community," The World Bank, Policy Research Working Paper WPS 1173 , September.

Whalley, John (1985), Trade Liberalization among World trading Areas, (Cambridge: MIT Press).

World Bank (1995), "Egypt: Into the Next Century: Volume 1, Macroeconomic Framework." 
TABLE 1: SECTORAL OUTPUT, FACTOR-USE, AND TRADE SHARES, 1990

\begin{tabular}{|c|c|c|c|c|c|c|}
\hline SECTOR & (1) & $\begin{array}{l}\text { Output } \\
\text { (2) }\end{array}$ & $\begin{array}{r}\text { Labor } \\
\text { (3) }\end{array}$ & $\begin{array}{l}\text { Capital } \\
\text { (4) }\end{array}$ & $\begin{array}{r}\text { Imports } \\
(5)\end{array}$ & Exports \\
\hline \multicolumn{7}{|l|}{ AGRICULTURE } \\
\hline 1. Vegetable products, food (VG1) & & 12.4 & 11.3 & 21.4 & 13.3 & 2.6 \\
\hline 2. Vegetable products, non-food (VG2) & & 1.7 & 1.7 & 2.9 & 0.0 & 0.1 \\
\hline 3. Animal products (ANI) & & 8.0 & 5.6 & 10.5 & 0.8 & 0.3 \\
\hline \multicolumn{7}{|l|}{ MINING AND QUARRYING } \\
\hline 4. Crude petroleum \& natural gas (OIL) & & 2.7 & 0.7 & 2.3 & 1.2 & 18.5 \\
\hline 5. Other extractive industries (MIN) & & 0.9 & 0.5 & 2.0 & 2.0 & 0.2 \\
\hline \multicolumn{7}{|l|}{ MANUFACTURING } \\
\hline 6. Food processing (FOO) & & 7.7 & 2.8 & 4.3 & 15.1 & 1.3 \\
\hline 7. Beverages (BEV) & & 0.6 & 0.3 & 0.3 & 0.0 & 0.0 \\
\hline 8. Tobacco products (TOB) & & 1.9 & 0.4 & 0.7 & 1.0 & 0.0 \\
\hline 9. Cotton ginning \& pressing (TX1) & & 1.2 & 0.1 & 0.1 & 0.5 & 4.2 \\
\hline 10. Cotton spinning \& weaving (TX2) & & 5.2 & 4.9 & 3.0 & 2.4 & 10.3 \\
\hline 11. Clothing: assembled \& pieces (CLO) & & 1.4 & 1.5 & 1.1 & 0.0 & 0.1 \\
\hline 12. Leather products, excl. shoes (LEA) & & 0.2 & 0.1 & 0.1 & 0.0 & 0.1 \\
\hline 13. Shoes (SHO) & & 0.4 & 0.4 & 0.2 & 0.0 & 0.0 \\
\hline 14. Wood \& products, excl. furniture (WOO) & & 1.1 & 0.3 & 0.9 & 5.0 & 0.1 \\
\hline 15. Furniture (FUR) & & 1.4 & 0.8 & 1.5 & 0.0 & 0.5 \\
\hline 16. Paper and printing (PAP) & & 1.5 & 0.8 & 0.9 & 3.3 & 0.9 \\
\hline 17. Chemicals \& products (CHE) & & 3.1 & 1.7 & 1.6 & 10.8 & 1.8 \\
\hline 18. Petroleum refining (PET) & & 2.7 & 0.8 & 3.2 & 1.2 & 3.3 \\
\hline 19. Rubber, plastics, \& products (RPL) & & 0.8 & 0.4 & 0.4 & 2.3 & 0.3 \\
\hline 20. Porcelain, china, pottery (POR) & & 0.3 & 0.2 & 0.2 & 0.4 & 0.1 \\
\hline 21. Glass \& products (GLA) & & 0.3 & 0.2 & 0.4 & 0.5 & 0.1 \\
\hline 22. Mineral products, nei (MPD) & & 1.7 & 1.0 & 1.8 & 0.4 & 0.0 \\
\hline 23. Iron, steel, base metals (MET) & & 2.8 & 1.4 & 2.5 & 2.6 & 0.8 \\
\hline 24. Machinery \& appliances (MAC) & & 3.5 & 2.7 & 1.7 & 23.1 & 4.6 \\
\hline 25. Transportation equipment (TRA) & & 1.0 & 0.9 & 0.5 & 5.9 & 0.4 \\
\hline 26. Other manufacturing (OMF) & & 0.1 & 0.1 & 0.0 & 0.5 & 0.1 \\
\hline \multicolumn{7}{|l|}{ SERVICES AND OTHER } \\
\hline 27. Electricity, gas, \& water (ELE) & & 1.7 & 2.4 & 0.8 & 0.2 & 0.7 \\
\hline 28. Construction $(\mathrm{CON})$ & & 5.5 & 5.0 & 4.3 & 0.2 & 0.8 \\
\hline 29. Trade (TRD) & & 7.1 & 5.0 & 14.2 & 0.3 & 5.6 \\
\hline 30. Restaurants, hotels (RES) & & 2.3 & 1.8 & 1.8 & 0.0 & 5.0 \\
\hline 31. Transport \& storage (TRN) & & 6.0 & 5.3 & 5.4 & 1.3 & 31.9 \\
\hline 32. Communications (COM) & & 0.8 & 0.9 & 1.5 & 0.1 & 0.4 \\
\hline 33. Financial establishments (FIN) & & 1.5 & 3.7 & 1.4 & 1.1 & 0.0 \\
\hline 34. Insurance (INS) & & 0.3 & 0.6 & 0.2 & 0.0 & 0.5 \\
\hline \multicolumn{7}{|l|}{ 35. Real estate, business services } \\
\hline \& housing services (HSG) & & 2.8 & 2.1 & 4.7 & 3.9 & 0.0 \\
\hline 36. Social \& community services (SER) & & 6.0 & 29.3 & 0.3 & 0.1 & 0.2 \\
\hline 37. Recreational \& cultural services (REC) & & 0.5 & 1.2 & 0.2 & 0.2 & 3.2 \\
\hline 38. Personal services (PER) & & 0.9 & 1.4 & 0.7 & 0.0 & 0.0 \\
\hline
\end{tabular}

Source: CAPMAS (1990, 1994a), World Bank (1995). 
TABLE 2: POLICY VARIABLES AND EU TRADE SHARES BY SECTOR, 1994

\begin{tabular}{|c|c|c|c|c|c|}
\hline SECTOR & $\begin{array}{c}\text { GST } \\
(1)\end{array}$ & $\begin{array}{c}\text { Capital Tax } \\
\text { (2) }\end{array}$ & $\begin{array}{c}\text { Tariff Rate } \\
\text { (3) }\end{array}$ & $\begin{array}{l}\text { EU Import } \\
\text { (4) }\end{array}$ & $\begin{array}{c}\text { EU Export } \\
\text { (5) }\end{array}$ \\
\hline \multicolumn{6}{|c|}{ AGRICULTURE } \\
\hline 1. VG1 & 0.0 & 0.0 & 2.5 & 11.7 & 27.0 \\
\hline 2. VG2 & 10.0 & 0.0 & 6.7 & 37.0 & 49.3 \\
\hline 3. ANI & 0.0 & 0.0 & 4.4 & 82.7 & 35.2 \\
\hline \multicolumn{6}{|c|}{ MINING AND QUARRYING } \\
\hline 4. OIL & 0.0 & 18.0 & 8.2 & 52.0 & 30.6 \\
\hline 5. MIN & 10.0 & 18.0 & 7.0 & 17.7 & 56.8 \\
\hline \multicolumn{6}{|c|}{ MANUFACTURING } \\
\hline 6. FOO & 0.0 & 18.0 & 6.8 & 40.3 & 20.1 \\
\hline 7. BEV & 10.0 & 18.0 & 953.2 & 41.7 & 1.2 \\
\hline 8. ТОВ & 10.0 & 18.0 & 65.5 & 27.0 & 0.4 \\
\hline 9. TX1 & 10.0 & 18.0 & 17.3 & 36.9 & 33.7 \\
\hline 10. TX2 & 10.0 & 18.0 & 23.3 & 33.4 & 72.4 \\
\hline 11. CLO & 10.0 & 18.0 & 53.7 & 12.4 & 34.7 \\
\hline 12. LEA & 10.0 & 18.0 & 34.8 & 25.7 & 48.8 \\
\hline 13. SHO & 10.0 & 18.0 & 51.8 & 16.0 & 20.5 \\
\hline 14. WOO & 5.0 & 18.0 & 8.1 & 39.8 & 1.5 \\
\hline 15. FUR & 10.0 & 18.0 & 46.9 & 57.0 & 14.9 \\
\hline 16. PAP & 0.0 & 18.0 & 13.3 & 46.8 & 1.6 \\
\hline 17. CHE & 5.0 & 18.0 & 8.9 & 62.6 & 31.3 \\
\hline 18. PET & 0.0 & 18.0 & 7.1 & 48.4 & 58.5 \\
\hline 19. RPL & 10.0 & 18.0 & 15.6 & 42.8 & 41.3 \\
\hline 20. POR & 10.0 & 18.0 & 43.5 & 47.4 & 42.2 \\
\hline 21. GLA & 10.0 & 18.0 & 29.6 & 63.3 & 9.3 \\
\hline 22. MPD & 5.0 & 18.0 & 18.1 & 61.6 & 4.8 \\
\hline 23. MET & 10.0 & 18.0 & 17.2 & 35.5 & 68.3 \\
\hline 24. MAC & 25.0 & 18.0 & 17.9 & 59.4 & 9.5 \\
\hline 25. TRA & 25.0 & 18.0 & 41.2 & 33.8 & 3.6 \\
\hline 26. OMF & 10.0 & 18.0 & 19.3 & 47.6 & 24.4 \\
\hline \multicolumn{6}{|c|}{ SERVICES AND OTHER } \\
\hline 27. ELE & 2.5 & 23.0 & 15.0 & 44.6 & 44.7 \\
\hline 28. CON & 10.0 & 23.0 & 15.0 & 44.6 & 44.7 \\
\hline 29. TRD & 8.0 & 23.0 & 15.0 & 44.6 & 44.7 \\
\hline 30. RES & 8.0 & 23.0 & 15.0 & 44.6 & 44.7 \\
\hline 31. TRN & 0.0 & 23.0 & 15.0 & 44.6 & 44.7 \\
\hline 32. COM & 5.0 & 23.0 & 15.0 & 44.6 & 44.7 \\
\hline 33. FIN & 8.0 & 23.0 & 15.0 & 44.6 & 44.7 \\
\hline 34. INS & 0.0 & 23.0 & 15.0 & 44.6 & 44.7 \\
\hline 35. HSG & 8.0 & 23.0 & 15.0 & 44.6 & 44.7 \\
\hline 36. SER & 10.0 & 23.0 & 15.0 & 44.6 & 44.7 \\
\hline 37. REC & 8.0 & 23.0 & 15.0 & 44.6 & 44.7 \\
\hline 38. PER & 10.0 & 23.0 & 15.0 & 44.6 & 44.7 \\
\hline
\end{tabular}

Note: regional trade shares in services are assumed to equal their respective shares in merchandise imports and exports. Source: World Bank data, Authors' concordance. 
TABLE 3. ECONOMIC EFFECTS OF TAX REFORM ALONE

\begin{tabular}{lrlrrr}
\hline Panel One: Reform of GST & & & & \\
\multicolumn{1}{l}{} & (A) & (B) & \multicolumn{1}{c}{ (C) } & \multicolumn{1}{c}{ (D) } & \multicolumn{1}{l}{ (E) } \\
Welfare & -0.22 & 0.42 & 0.42 & 0.83 & 0.42 \\
E Rate & 6.43 & 4.43 & 1.11 & -3.87 & -2.08 \\
GST Rates & - & - & -50.61 & - & - \\
K Tax Rates & 56.67 & - & - & -47.36 & - \\
LS Tax (ELs b) & - & 2.33 & - & - & -2.24 \\
PL Wage & 5.71 & 4.92 & 1.59 & -2.34 & -1.62 \\
K Price & -2.12 & 4.18 & 0.87 & 3.50 & -2.31
\end{tabular}

(A): Remove GST, maintain distorted $\mathrm{K}$ tax, replace revenues with $\mathrm{K}$ tax

(B): Remove GST, maintain distorted K tax, replace revenues with LS tax

(C): Unify GST, maintain distorted K tax, replace revenues with GST

(D): Unify GST, maintain distorted K tax, replace revenues with K tax

(E): Unify GST, maintain distorted K tax, replace revenues with LS tax

Panel Two: Reform of Capital Tax

\begin{tabular}{lrrrrr} 
& (A) & \multicolumn{1}{c}{$(\mathrm{B})$} & \multicolumn{1}{c}{$(\mathrm{C})$} & \multicolumn{1}{c}{ (D) } & \multicolumn{1}{c}{$(\mathrm{E})$} \\
Welfare & 0.43 & 0.82 & 1.01 & 0.82 & 0.82 \\
E Rate & -7.25 & -4.10 & -1.68 & -4.10 & -4.10 \\
GST Rates & 86.00 & - & -59.19 & - & - \\
K Tax Rates & - & - & - & -45.12 & - \\
LS Tax (ELs b) & - & 3.41 & - & - & -2.47 \\
PL Wage & -5.09 & -1.59 & 1.12 & -1.59 & -1.59 \\
K Price & 10.18 & 13.77 & 2.61 & 5.90 & 0.19
\end{tabular}

(A): Remove K tax, maintain distorted GST, replace revenues with GST

(B): Remove K tax, maintain distorted GST, replace revenues with LS tax

(C): Unify K tax, maintain distorted GST, replace revenues with GST

(D): Unify K tax, maintain distorted GST, replace revenues with K tax

(E): Unify K tax, maintain distorted GST, replace revenues with LS tax

Panel Three: Joint Tax Reform

\begin{tabular}{lrrrrr} 
& $(\mathrm{A})$ & $(\mathrm{B})$ & $(\mathrm{C})$ & \multicolumn{1}{c}{$(\mathrm{D})$} & \multicolumn{1}{c}{$(\mathrm{E})$} \\
Welfare & 1.09 & 1.09 & 1.09 & 1.09 & 1.09 \\
E Rate & 0.14 & 0.14 & 0.14 & -10.00 & -6.10 \\
GST Rates & - & - & - & 69.44 & - \\
K Tax Rates & - & 35.72 & - & - & - \\
LS Tax (ELs b) & 7.98 & - & -1.85 & - & 3.07 \\
PL Wage & 3.15 & 3.15 & 3.15 & -7.29 & -3.28 \\
K Price & 18.57 & 0.15 & 4.42 & 6.58 & 11.19
\end{tabular}

(A): Remove GST and K Tax, replace revenues with LS tax

(B): Remove GST, unify K tax, replace revenues with $\mathrm{K}$ tax

(C): Remove GST, unify K tax, replace revenues with LS tax

(D): Remove K tax, unify GST, replace revenues with GST

(E): Remove K tax, unify GST, replace revenues with LS tax 
Panel One: Tariff Unification

\begin{tabular}{lrrr} 
& $(\mathrm{A})$ & $(\mathrm{B})$ & \multicolumn{1}{c}{$(\mathrm{C})$} \\
Welfare & 0.49 & 0.66 & 0.35 \\
E Rate & 0.94 & -1.55 & -0.43 \\
GST Rates & -32.77 & - & - \\
K Tax Rates & - & -28.68 & - \\
LS Tax (ELs b) & - & - & -1.33 \\
PL Wage & 1.74 & -0.19 & 0.22 \\
K Price & 2.02 & 4.23 & 0.72
\end{tabular}

(A): Maintain distorted taxes, replace revenues with GST

(B): Maintain distorted taxes, replace revenues with $\mathrm{K}$ tax

(C): Maintain distorted taxes, replace revenues with LS tax

Panel Two: FTA with European Union

\begin{tabular}{lrrr} 
& $(\mathrm{A})$ & \multicolumn{1}{c}{$(\mathrm{B})$} & \multicolumn{1}{c}{$(\mathrm{C})$} \\
Welfare & 0.31 & 0.32 & 0.29 \\
E Rate & 0.84 & 0.60 & 0.71 \\
GST Rates & -3.26 & - & - \\
K Tax Rates & - & -2.91 & - \\
LS Tax (ELs b) & - & - & -0.13 \\
PL Wage & 2.83 & 2.62 & 2.67 \\
K Price & 2.30 & 2.52 & 2.18
\end{tabular}

(A): Maintain distorted taxes, replace revenues with GST

(B): Maintain distorted taxes, replace revenues with $\mathrm{K}$ tax

(C): Maintain distorted taxes, replace revenues with LS tax

Panel Three: Full Unilateral Liberalization

\begin{tabular}{lrrr} 
& \multicolumn{1}{c}{$(\mathrm{A})$} & $(\mathrm{B})$ & \multicolumn{1}{c}{$(\mathrm{C})$} \\
Welfare & 0.78 & 0.68 & 0.89 \\
E Rate & 1.11 & 2.91 & 2.09 \\
GST Rates & 23.86 & - & - \\
K Tax Rates & - & 21.08 & - \\
LS Tax (ELs b) & - & - & 0.94 \\
PL Wage & 2.14 & 3.55 & 3.23 \\
K Price & 2.85 & 1.30 & 3.80
\end{tabular}
(A): Maintain distorted taxes, replace revenues with GST
(B): Maintain distorted taxes, replace revenues with $\mathrm{K}$ tax
(C): Maintain distorted taxes, replace revenues with LS tax 


\section{TABLE 5. ECONOMIC EFFECTS OF JOINT TAX REFORM AND TRADE POLICY REFORM}

Panel One: Reform of GST and Trade Policy Reform

\begin{tabular}{|c|c|c|c|c|c|c|c|c|c|c|c|c|c|c|c|}
\hline & (A) & (B) & (C) & (D) & (E) & $(C$ & $(\mathrm{H})$ & (I) & $(\mathrm{J})$ & $(\mathrm{K})$ & (L) & (M) & $(\mathrm{N})$ & (O) & \\
\hline Welfare & -0.19 & -0.84 & -0.54 & 0.70 & 0.63 & 1.21 & 0.70 & 0.63 & 1.21 & 1.01 & 0.72 & 1.10 & 0.70 & 0.63 & 1.21 \\
\hline E Rate & 6.70 & 8.80 & 11.68 & 4.00 & 5.17 & 6.61 & -0.19 & -0.77 & -0.84 & -3.83 & -1.74 & 0.47 & -2.48 & -1.38 & -0.03 \\
\hline GST Rates & - & - & - & - & - & - & -36.74 & -9.94 & 13.12 & - & - & - & - & - & \\
\hline K Tax Rates & 74.58 & 112.6 & 142.6 & - & - & - & - & - & 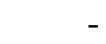 & -35.08 & -9.76 & 12.98 & - & - & \\
\hline LS Tax (ELs b) & & & & 2.97 & 4.23 & 5.32 & - & - & _ & - & & - & -1.62 & -0.44 & 0.58 \\
\hline PL Wage & 6.17 & 9.73 & 10.46 & 5.14 & 7.73 & 8.27 & 0.90 & 1.65 & 0.70 & -1.94 & 0.84 & 1.73 & -1.41 & 1.02 & 1.52 \\
\hline Price & -3.21 & -5.33 & -6.70 & 4.92 & 6.45 & 8.15 & 0.69 & 0.44 & 0.59 & 2.64 & 0.97 & -0.11 & -1.61 & -0.18 & 1.41 \\
\hline
\end{tabular}

(A): Remove GST, unify tariffs, maintain distorted $\mathrm{K}$ tax, replace revenues with $\mathrm{K}$ tax

(B): Remove GST, FTA with EU, maintain distorted K tax, replace revenues with K tax

(C): Remove GST, unilateral liberalization, maintain distorted K tax, replace revenues with $\mathrm{K}$ tax

(D): Remove GST, unify tariffs, maintain distorted K tax, replace revenues with LS tax

(E): Remove GST, FTA with EU, maintain distorted K tax, replace revenues with LS tax

(F): Remove GST, unilateral liberalization, maintain distorted K tax, replace revenues with LS tax

(G): Unify GST, unify tariffs, maintain distorted K tax, replace revenues with GST

(H): Unify GST, FTA with EU, maintain distorted K tax, replace revenues with GST

(I): Unify GST, unilateral liberalization, maintain distorted K tax, replace revenues with GST

(J): Unify GST, unify tariffs, maintain distorted $\mathrm{K}$ tax, replace revenues with $\mathrm{K}$ tax

(K): Unify GST, FTA with EU, maintain distorted K tax, replace revenues with K tax

(L): Unify GST, unilateral liberalization, maintain distorted K tax, replace revenues with $\mathrm{K}$ tax

(M): Unify GST, unify tariffs, maintain distorted K tax, replace revenues with LS tax

(N): Unify GST, FTA with EU, maintain distorted K tax, replace revenues with LS tax

(O): Unify GST, unilateral liberalization, maintain distorted K tax, replace revenues with LS tax 


\section{TABLE 5. ECONOMIC EFFECTS OF JOINT TAX REFORM AND TRADE POLICY REFORM, CONTINUED}

Panel Two: Reform of Capital Tax and Trade Policy Reform

\begin{tabular}{|c|c|c|c|c|c|c|c|c|c|c|c|c|c|c|c|}
\hline & (A) & (B) & (C) & (D) & (E) $\quad($ & ) $\quad(C$ & (H & (I) & $(\mathrm{J})$ & $(\mathrm{K})$ & (L) & $(\mathrm{M})$ & $(\mathrm{N})$ & $(\mathrm{O})$ & \\
\hline Welfare & 0.77 & 0.38 & 0.68 & 1.19 & 1.00 & 1.47 & 1.31 & 1.04 & 1.42 & 1.19 & 1.00 & 1.47 & 1.19 & 1.00 & 1.47 \\
\hline E Rate & -8.46 & -8.54 & -8.61 & -4.66 & -3.50 & -2.33 & -2.85 & -2.94 & -2.93 & -4.66 & -3.50 & -2.33 & -4.66 & -3.50 & -2.33 \\
\hline SST Rates & 105.3 & 141.9 & 178.7 & - & - & - & -44.89 & -14.05 & 15.22 & - & - & - & & & 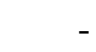 \\
\hline Rates & - & 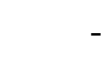 & - & - & - & - & - & - & - & -33.81 & -10.60 & 11.37 & - & - & \\
\hline Is & - & - & - & 4.09 & 5.44 & 6.72 & - & - & - & - & - & - & -1.84 & -0.57 & 0.60 \\
\hline L Wage & -5.59 & -4.99 & -5.55 & -1.36 & 0.70 & 1.46 & 0.67 & 1.33 & 0.79 & -1.34 & 0.70 & 1.46 & -1.36 & 0.70 & 1.46 \\
\hline Price & 10.21 & 10.46 & 10.98 & 14.58 & 16.30 & 18.31 & 2.73 & 2.99 & 3.58 & 5.14 & 3.73 & 2.80 & 0.90 & 2.42 & 4.19 \\
\hline
\end{tabular}

(A): Remove K tax, unify tariffs, maintain distorted GST, replace revenues with GST

(B): Remove K tax, FTA with EU, maintain distorted GST, replace revenues with GST

(C): Remove K tax, unilateral liberalization, maintain distorted GST, replace revenues with GST

(D): Remove K tax, unify tariffs, maintain distorted GST, replace revenues with LS tax

(E): Remove K tax, FTA with EU, maintain distorted GST, replace revenues with LS tax

(F): Remove K tax, unilateral liberalization, maintain distorted GST, replace revenues with LS tax

(G): Unify K tax, unify tariffs, maintain distorted GST, replace revenues with GST

(H): Unify K tax, FTA with EU, maintain distorted GST, replace revenues with GST

(I): Unify K tax, unilateral liberalization, maintain distorted GST, replace revenues with GST

(J): Unify K tax, unify tariffs, maintain distorted GST, replace revenues with K tax

(K): Unify K tax, FTA with EU, maintain distorted GST, replace revenues with K tax

(L): Unify K tax, unilateral liberalization, maintain distorted GST, replace revenues with K tax

(M): Unify K tax, unify tariffs, maintain distorted GST, replace revenues with LS tax

(N): Unify K tax, FTA with EU, maintain distorted GST, replace revenues with LS tax

(O): Unify K tax, unilateral liberalization, maintain distorted GST, replace revenues with LS tax 


\section{TABLE 5. ECONOMIC EFFECTS OF JOINT TAX REFORM AND TRADE POLICY REFORM, CONTINUED}

\begin{tabular}{|c|c|c|c|c|c|c|c|c|c|c|c|c|c|c|c|}
\hline \multicolumn{16}{|c|}{ Panel Three: Joint Tax Reform and Trade Policy Reform } \\
\hline & (A) & (B) & (C) & (D) & (E) & (F) & $(\mathrm{H})$ & (I) & $(\mathrm{J})$ & $(\mathrm{K})$ & $(\mathrm{L})$ & $(\mathrm{M})$ & $(\mathrm{N})$ & $(\mathrm{O})$ & \\
\hline Welfare & 1.38 & 1.19 & 1.63 & 1.38 & 1.19 & 1.63 & 1.38 & 1.19 & 1.63 & 1.39 & 1.19 & 1.63 & 1.38 & 1.19 & 1.63 \\
\hline E Rate & -0.43 & 0.77 & 1.99 & -0.43 & 0.77 & 1.99 & -0.43 & 0.77 & 1.99 & -11.27 & -11.79 & -12.13 & -6.63 & -5.51 & -4.37 \\
\hline GST Rates & - & - & - & - & - & - & - & - & - & 83.97 & 114.3 & 141.9 & - & - & - \\
\hline K Tax Rates & - & - & - & 47.69 & 74.51 & 98.95 & - & - & - & - & - & - & - & - & - \\
\hline LS Tax (ELs b) & 8.63 & 10.04 & 11.34 & - & - & - & 2.45 & 3.78 & 4.97 & - & - & - & 3.69 & 5.02 & 6.24 \\
\hline PL Wage & 3.37 & 5.55 & 6.31 & 3.37 & 5.55 & 6.31 & 3.37 & 5.55 & 6.31 & -7.88 & -7.61 & -8.41 & -3.07 & -1.03 & -0.32 \\
\hline K Price & 19.41 & 21.21 & 23.31 & -0.51 & -1.97 & -2.87 & 5.16 & 6.75 & 8.60 & 6.40 & 6.11 & 6.24 & 11.97 & 13.66 & 15.63 \\
\hline
\end{tabular}

(A): Remove GST and K tax, unify tariffs, replace revenues with LS tax

(B): Remove GST and K tax, FTA with EU, replace revenues with LS tax

(C): Remove GST and K tax, unilateral liberalization, replace revenues with LS tax

(D): Remove GST, unify K tax, unify tariffs, replace revenues with K tax

(E): Remove GST, unify K tax, FTA with EU, replace revenues with K tax

(F): Remove GST, unify K tax, unilateral liberalization, replace revenues with $\mathrm{K}$ tax

(G): Remove GST, unify K tax, unify tariffs, replace revenues with LS tax

(H): Remove GST, unify K tax, FTA with EU, replace revenues with LS tax

(I): Remove GST, unify K tax, unilateral liberalization, replace revenues with LS tax

(J): Remove K tax, unify GST, unify tariffs, replace revenues with GST

(K): Remove K tax, unify GST, FTA with EU, replace revenues with GST

(L): Remove K tax, unify GST, unilateral liberalization, replace revenues with GST

(M): Remove K tax, unify GST, unify tariffs, replace revenues with LS tax

(N): Remove K tax, unify GST, FTA with EU, replace revenues with LS tax

(O): Remove K tax, unify GST, unilateral liberalization, replace revenues with LS tax 
TABLE 6. DECOMPOSITION OF WELFARE GAINS FROM TAX REFORM AND TRADE REFORM

Panel One: Joint Tax Reform and Unilateral Trade Liberalization

Lump-Sum Replacement $\quad$ GST Replacement

Remove or Unify both Taxes Remove or Unify Both Taxes

K Tax Replacement

$\begin{array}{lccc} & \text { Remove or Unify both Taxes } & \text { Remove or Unify Both Taxes } & \text { Remove or Unify Both Taxes } \\ \text { Total } & 1.63 & 1.63 & 1.63 \\ \text { Tax } & 1.09 & 1.09 & 1.09 \\ \text { Trade } & 0.89 & 0.78 & 0.68 \\ \text { Interaction } & -0.35 & -0.24 & -0.14\end{array}$

Panel Two: GST Reform and Unilateral Trade Liberalization

\begin{tabular}{lcccrr} 
& Lump-Sum Replacement & GST Replacement & & \multicolumn{2}{c}{ K Tax Replacement } \\
\cline { 2 - 3 } Remove or Unify GST & 1.21 & Unify GST & & Remove GST & Unify GST \\
Total & 0.42 & 1.21 & & -0.54 & 1.10 \\
Tax & 0.89 & 0.42 & & -0.22 & 0.83 \\
Trade & -0.10 & 0.78 & & 0.68 & 0.68 \\
Interaction & & +0.01 & & -0.08 & -0.41
\end{tabular}

Panel Three: Capital Tax Reform and Unilateral Trade Liberalization

Lump-Sum Replacement

Remove or Unify K Tax

Total $\quad 1.47$

Tax 0.82

Trade $\quad 0.89$

Interaction $\quad-0.24$
GST Replacement

Remove K Tax Unify K Tax

0.68

0.43

0.78

$-0.53$

1.42

1.01

0.78

$-0.37$
K Tax Replacement

Unify $K$ Tax

1.47

0.82

0.68

$-0.03$ 
FIGURE 1

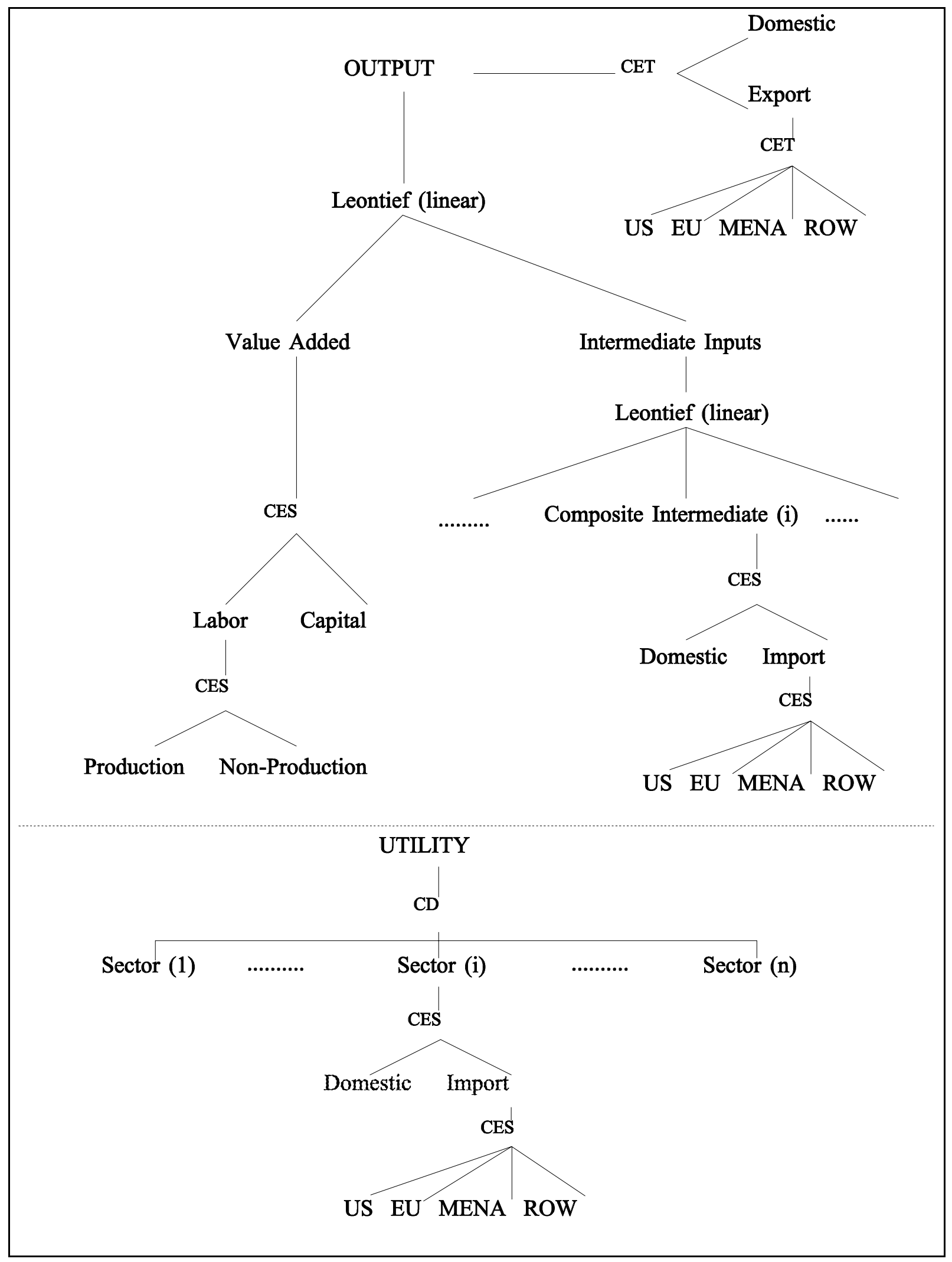


